\title{
Nupela marvanii sp. nov., and $N$. lapidosa (KRASSKe) LANGE-BERTALOT in Poland with notes on the distribution and ecology of the genus Nupela (Bacillariophyta)
}

\author{
Agata Z. WOJTAL \\ W. Szafer Institute of Botany, Polish Academy of Sciences, Lubicz 46, 31-512, Kraków, Poland; e-mail: a.wojtal@ \\ botany.pl
}

\begin{abstract}
Two species of Nupela were identified in a spring and in a small spring-fed pool in the Polish Tatra Mts, - these were N. lapidosa and Nupela sp. The second species is described as $N$. marvanii. The new species is characterized by heteropolar, narrowly elliptic valves with capitate apices. Sternum valve has very short, sometimes rudimental raphe branches. Under a light microscope transapical striae are not discernible. Externally both valves are covered with hymen. The central area of sternum valves has irregular silicate thickenings. Proximal raphe fissures are straight and terminate in small pores. Distal raphe fissures double-deflected into the same side of the valve, form ?-shaped structures that extend onto the mantle. Internally visible linear-lanceolate axial area, which forms unilateral fascia on raphe valve, which reaches valve margin. Proximal raphe fissures are T-shaped. Distal raphe fissures are straight, and terminate in small, linear helictoglossa. Sternum valve has large, clearly visible internally, asymmetrically lanceolate central area and discernible externally reinforced median costa. Raphe fissures are strongly reduced, rudimental. The areole are round to elliptical, expanded along the transapical axis, with the wider opening on the external surface. An irregular row of similar areoles is present along pleural side of valve. Both species are documented with LM and SEM micrographs and briefly discussed. The distribution and autecology of 46 Nupela members are summarized.
\end{abstract}

Key words: diatoms, distribution, oligotrophy, species nova, Tatra Mts, taxonomy

\section{Introduction}

Nupela is a freshwater genus that originally comprised only $N$. giluwensis VyVERMAN et COMPÈRE and $N$. hagensis VyVERMAN, described from material collected in Papua New Guinea. The third species, mentioned by VyVERMAN \& COMPÈre (1991) as a possible member of the genus, was Anomoeoneis paludigena SCHERER [= Nupela paludigena (SCHERER) LANGE-BERTALOT], known from south-eastern part of the Atlantic Coastal Plain of North America. Since 1991 the genus has expanded to include over 40 worldwide taxa (Monnier et al. 2003, Metzeltin \& LAngeBertalot 2007, Siver et al. 2007, Kulikovskiy et al. (in press)). Most of them were described after 1991, as a result of a better recognition of diatom flora in the tropical zone (e.g. VyVERMAN 1991, Moser et al. 1998, Metzeltin \& Lange-Bertalot 2007), and the application of a scanning electron microscope for the identification of small and finely ornamented diatoms (e.g. RumRich et al.
2000, Potapova et al. 2003, Siver \& Hamilton 2005, Siver et al. 2007).

Since the original description of the genus the morphological concept of Nupela has been broadened including distinctly isovalvar and heterovalvar species with respect to the degree of development of the raphe (SIVER et al. 2007) but both groups share the features specific for Nupela, e.g. areolae morphology, which is regarded as one of the most important and stable feature of the genus (PotApova et al. 2003, Siver et al. 2007). The inconspicuousness of most Nupela species and the frustules fine ornamentation make them difficult to identify, especially when only a light microscope is used. Additional inconvenience in estimating the species distribution is their sparseness and that they are easy to be overlooked. Only a few species, such as Nupela lapidosa (KRASSKE) LANGE-BERTALOT are known as quite common in certain areas (WeRUM \& LANGE-BERTALOT 2004).

The Nupela species occur mainly in oligotrophic environments that possess unique 
diatom flora including threatened oligotraphentic Kobayasiella, Brachysira, Eunotia, and Neidium species. During an investigation of diatoms in springs in the Tatra Mts, Nupela lapidosa was found. The second species found is described as a new species.

\section{Materials and methods}

The squeezed water from submerged mosses in the spring and bottom sediment from a small pool, approximately $100 \mathrm{~m}$ below the spring were collected (30 September 2008) in the Dolina Bystrej Wody valley situated in the Polish Tatra Mts, $49^{\circ} 14.841^{\prime} \mathrm{N}$ and $19^{\circ} 58.289^{\prime} \mathrm{E}$, at an elevation of $1289 \mathrm{~m}$ a.s.l. The samples were preserved in a $30 \%$ water solution of formaldehyde (formalin). Water properties from the spring temperature, conductivity and $\mathrm{pH}$ were measured using an ELMETRON CC-102 and $\mathrm{CP}-103$ conductivity and $\mathrm{pH}$ meters, respectively. Other parameters were determined at the same time immediately after collection, with a Spectroquant Nova 60 (Merck). Alkalinity, fluor, bromine, and sulfates concentrations were measured by means of ion chromatography (Dionex 100) atomic absorption spectrophotometry (AAS) and flame AAS techniques in Institute of Botany laboratory in Szarów. The physical and chemical characteristics of the water in the spring were as follow: temperature $=7.0^{\circ} \mathrm{C}$, conductivity $=40$ $\mu \mathrm{S} \mathrm{cm}^{-1} ; \mathrm{pH}=5.5 ;$ oxygen $=10.5 \mathrm{mg} \mathrm{l}^{-1}, \mathrm{Cl}^{-}=16.0 \mathrm{mg}$ $\mathrm{l}^{-1} ; \mathrm{NO}_{3}^{-}=2.7 \mathrm{mg} \mathrm{l}^{-1}, \mathrm{PO}_{4}{ }^{3-}=0.2 \mathrm{mg} \mathrm{l}^{-1} ; \mathrm{SO}_{4}{ }^{2-}=0.92 \mathrm{mg}$ $\mathrm{l}^{-1}$; alkalinity $=1.11 \mathrm{mval} \mathrm{l}^{-1} ; \mathrm{Ca}^{2+}=21 \mathrm{mg} \mathrm{l}^{-1} ; \mathrm{F}^{-}=0.11$ $\mathrm{mg} \mathrm{l}^{-1} ; \mathrm{Br}^{-}=0.43 \mathrm{mg} \mathrm{l}^{-1}$.

The samples for diatom analysis were treated with $10 \% \mathrm{HCl}$, washed several times with distilled water, and thereafter boiled in concentrated acids $\left(\mathrm{H}_{2} \mathrm{SO}_{4}, \mathrm{HNO}_{3}\right)$, in order to remove organic matter. After washing several times with distilled water the cleaned diatom material was air-dried on coverslips and mounted in Naphrax ${ }^{\circledR}$. Observations of the diatoms were performed with a Nikon Eclipse 600 light microscope equipped with Nomarski phase contrast. The micrographs were taken with a Nikon DS-Fi 1 camera. For SEM analysis the material was pipetted onto cover glasses, air-dried and affixed to an aluminium stub with double-sided transparent tape. The stubs were sputter coated with gold and viewed with a Hitachi S-4700 scanning electron microscope. SEM micrographs were taken in the Laboratory of Field Emission Scanning Electron Microscopy and Microanalysis at the Institute of Geological Sciences of the Jagiellonian University. Data on the distribution of the species and their ecology were obtained from cited literature and also from Iconotheca of Algae of Department of Phycology, W. Szafer Institute of Botany, Polish Academy of Sciences, Kraków.

The data on Nupela species include description or transfer literature citation, basionym (if transferred), type locality information, general ecology and distribution data.

\section{Results and discussion}

During the initial stage of the study of the diatom flora in the Tatra Mts springs two Nupela members were foundinthewaters of the Dolina Bystrejvalley. The first species - Nupela lapidosa belongs to the most common Nupela representatives, present in $56 \%$ of springs on metamorphic bedrock, $50 \%$ on basalt bedrock and $17 \%$ on granitic bedrock in Germany (Werum \& Lange-Bertalot 2004). In Poland it is reported to occur mainly in the Tatra Mts (KAWECKA 1970, 1971, 1977, 1980, W ASYLIK 1971, KAWECKA \& GALAs 2003), but also from one spring on the Wyżyna Krakowsko-Częstochowska upland (SKALSKA 1966a, 1966b).

\section{Nupela lapidosa (KRASSKe) LANGE-BERTALOT Figs 1-5, 14-25.}

Basionym: Achnanthes lapidosa KrassKe 1929, Botan. Arch. 27, p. 350; fig. 9 a, b.

LM. Frustules heterovalvar. Valves slightly transapically curved, lanceolate, 18.5-22.6 $\mu \mathrm{m}$ long and $4.8-5.6 \mu \mathrm{m}$ broad. Under light microscope transapical striae clearly visible on both valves, slightly radiate in the middle valve part and becoming strongly radiate towards apices. Axial area linear-lanceolate on raphe valve, and broadly lanceolate on sternum raphe. Central area asymmetrical, unilaterally expanded up to the valve margin (sternum valve) or almost up to valve margin (raphe valve).

SEM. Coarse ornamentation of the external valve surface clearly visible (Figs 14-17). The outside areola openings discernible despite hymen covering and pores occlusion by complex cribra (Fig. 17). Externally central area often covered with pit-like depressions (Fig. 15), visible in LM as shadows. Raphe filiform, with elongated drop-like central terminals. Polar terminals double-deflected into the same side of the valve, form ?-shaped structures that extend onto the mantle, where they terminate in pores. Internally raphe valve with central raphe terminals strongly deflected to the same side. Polar raphe terminals end in straight helictoglossa. Sternum valve without raphe or with raphe reduced to very short slit, discernible 

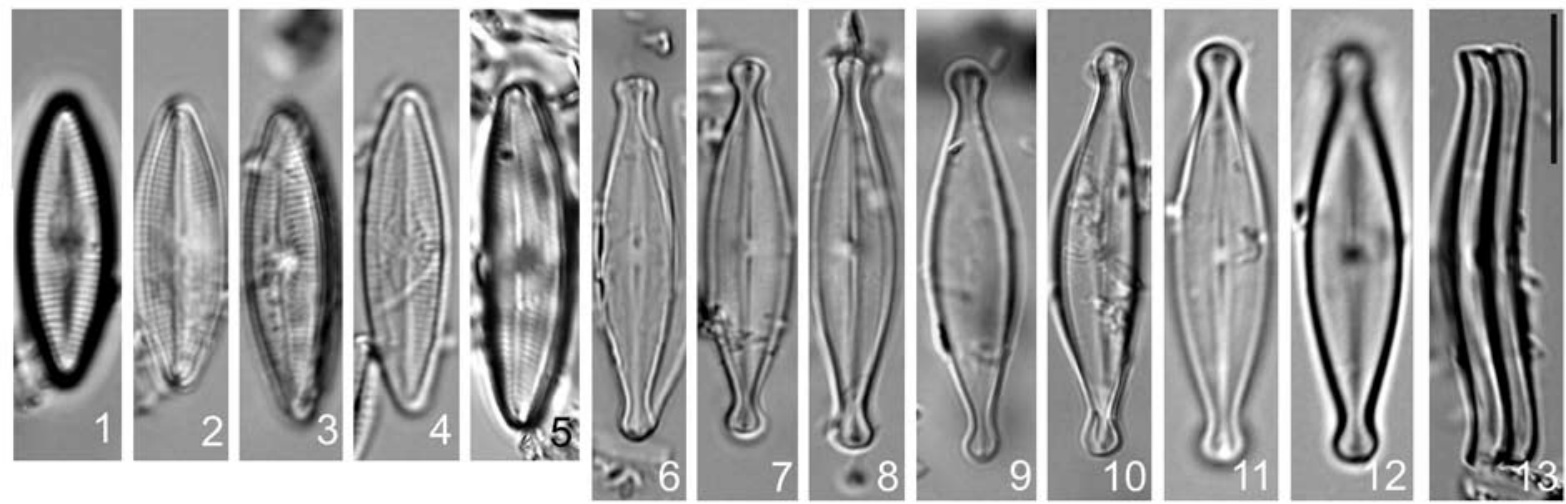

Figs 1-5. Nupela lapidosa (KRAsske) Lange-Bertalot. Figs 6-13. N. marvanii sp. nov.: $(1,9,12)$ sternum valves; $(2-8,10,11)$ raphe valves, (13) girdle view of two frustules; (11) holotypus, focus at raphe valve; (12) holotypus, focus at sternum valve. Light microscope (LM). Scale bar $10 \mu \mathrm{m}$.

from the inner part of the valve in SEM. Internally visible linear-lanceolate axial area, which forms on raphe valve unilateral fascia, reaching the valve margin. Central area of sternum valves with irregular silicate thickenings visible externally. Valve face separated from the mantle with distinct crest. Transapical striae located in the depressions, interstria are elevated. Striae slightly radial in the middle of the valve and becoming radial towards apices $-19-24$ in $10 \mu \mathrm{m}$.

The ecological optimum of the species is in oligotrophic, circumneutral waters of low up to moderate conductivity (WERUM \& LANGEBERTALOT 2004).

\section{Nupela marvanii WoJTAL, sp. nov. Figs 6-13, 26-43}

Diagnosis. Valvae heteropolares, leviter curvatae, angusto-ellipticae, apicibus distincte capitatis, 24.0$28.5 \mu \mathrm{m}$ longae et 5.0-6.0 $\mu \mathrm{m}$ latae. Raphovalva cum raphe extermis proximalibus rectis in elevato centrali nodo positis. Areovalva cum ramis raphis brevissimis, aliquando rudimentalibus. Striae transapicales in LM invisibiles. Ambae valvae tectae hymene in SEM visibili. Areovalva cum area centrali irregularibus siliceis interrogationis, in limbum transgredientes. Raphovalva a parte inferior visa cum area axilliar lineari-lanceolata et fascia unilaterali. Proximales raphis fissurae instar litterae T. Distales raphis fissurae rectae in parva lineari helictoglossa terminatae. Areovalva cum area magna asymmetrice lanceolata et a parte interior distinct visa, et costa mediana externe incrassate. Fissurae raphis reductae, rudimentales. Striae transapicales in media parte valvae leniter radiatae, in parallelas et postea leniter convergentes transgredientes, $40-44$ in $10 \mu \mathrm{m}$. Striae transapicales in series longitudinales non dispositae. Areolae rotunda vel ellipticae in directione antapicali elongatae, cum aperture externe dilatata. Series irregularis areolarum iis supra descriptis similium iuxta limbum positum.

Description: Frustules heterovalvar. Valves slightly transapically curved, narrowly elliptic with distinctly capitate apices, 24.0-28.5 $\mu \mathrm{m}$ long and 5.0-6.0 $\mu \mathrm{m}$ broad. Raphe with straight proximal endings, situated on elevated central nodule. Sternum valve with very short, sometimes rudimental raphe branches. Under light microscope transapical striae not discernible.

Externally, under electron scanning microscope both valves covered with hymen (Figs 26-29, 36-39). Central area of sternum valves with irregular silicate thickenings. Proximal raphe fissures are straight and terminate as small teardrop-shaped pores. Distal raphe fissures double-deflected into the same side of the valve, form ?-shaped structures that extend onto the mantle.

Internally visible linear-lanceolate axial area, which forms on raphe valve unilateral fascia. Proximal raphe fissures T-shaped. Distal raphe fissures straight, terminate in small, linear helictoglossa. Sternum valve with large, clearly visible internally, asymmetrically lanceolate central area and discernible externally reinforced median costa. Raphe fissures strongly reduced, rudimental. Transapical striae slightly radial in the middle of the valve and become parallel, and then slightly convergent towards apices $-40-44$ in $10 \mu \mathrm{m}$. Transapical stria are not organized in longitudinal rows. The areole are round to elliptical, expanded along the transapical axis, with the wider opening on the external surface. An irregular row of similar areoles is present 

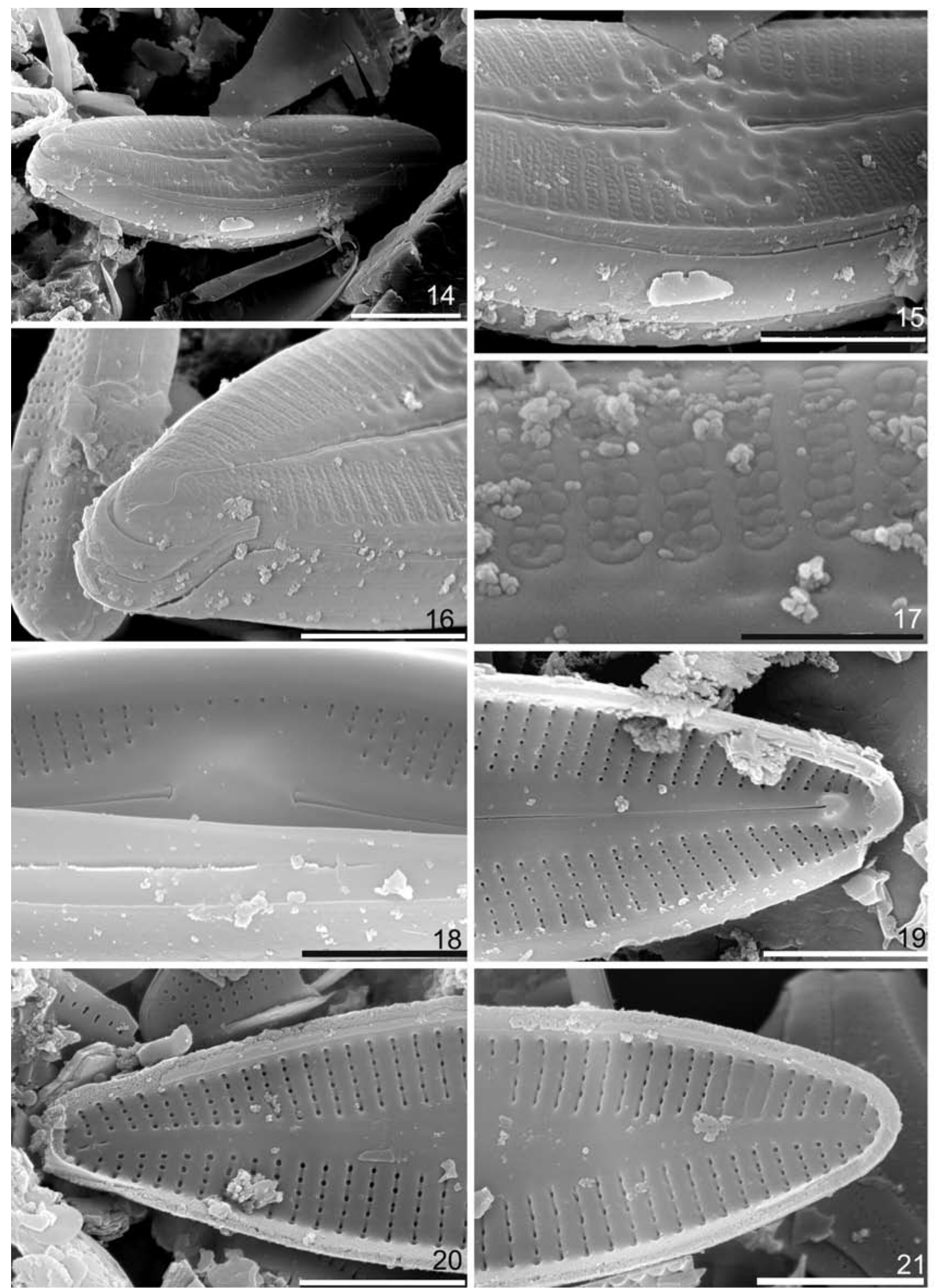

Figs 14-21. Nupela lapidosa: (15) central area with pit-like depressions; (16) polar terminals double-deflected into the same side of the valve, form ?-shaped structures, extend onto the mantle, where terminate in pores; (17) pores occlusion by complex cribra; (18) central raphe terminals strongly deflected to the same side; (19) polar raphe terminals in straight helictoglossa; $(20,21)$ valve with raphe reduced to very short slit or without raphe. Scanning electron microscope (SEM) external (14-17) and internal (18-21) view of raphe valve (14-19) and sternum $(20,21)$ valves. Scale bars $5 \mu \mathrm{m}$ (Fig. 14); $3 \mu \mathrm{m}$ (Figs 15, 16, 18-21). 

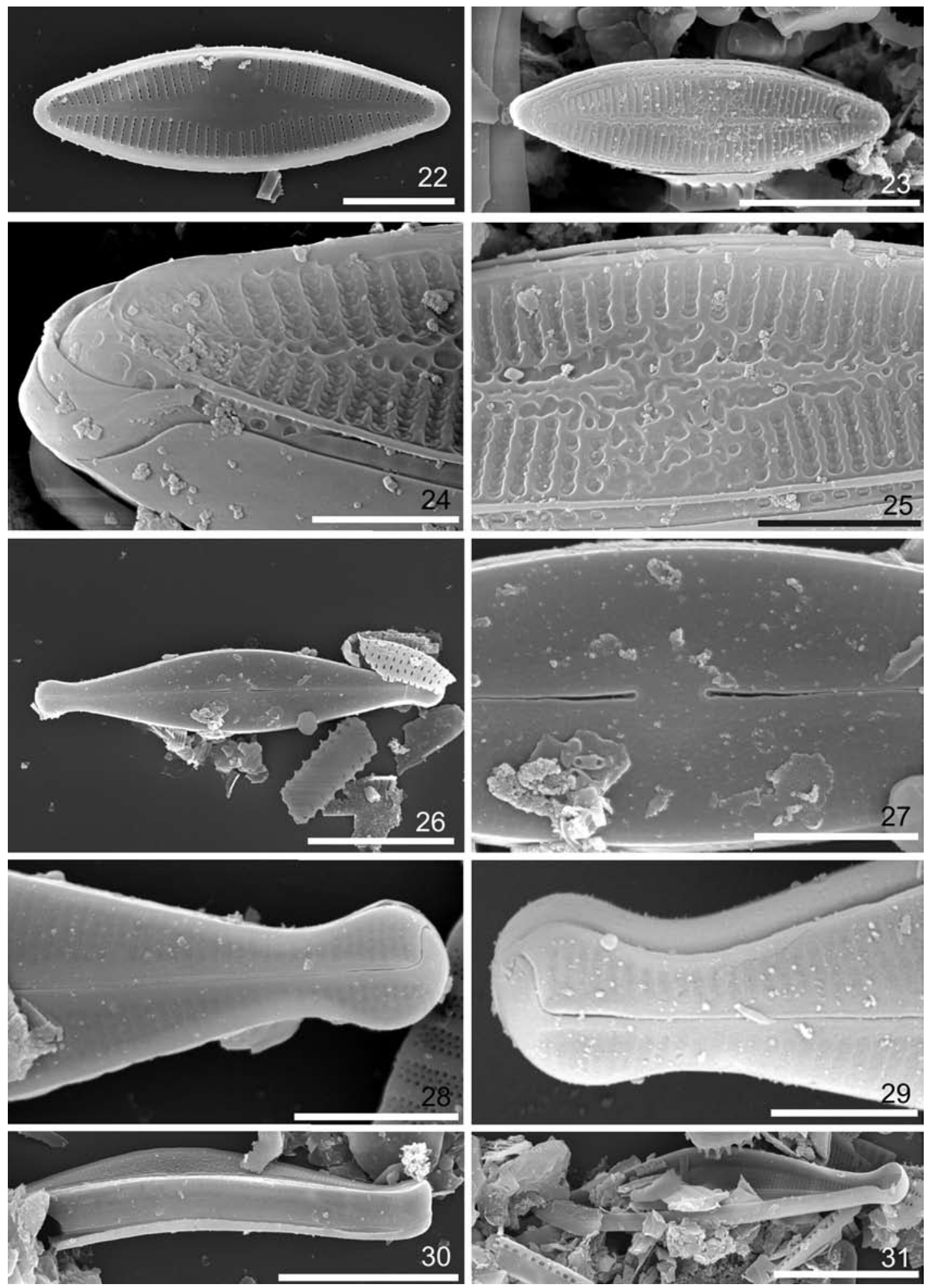

Figs 22-25. Nupela lapidosa: (22) linear-lanceolate axial area, which forms on raphe valve unilateral fascia, reaching the valve margin; $(24,25)$ valve face separated from the mantle with distinct crest, transapical striae located in the depressions, interstria elevated; Figs 26-31. N. marvanii sp. nov.: (28-29) proximal raphe fissures straight and terminate as small teardrop-shaped pores. Distal raphe fissures double-deflected into the same side of the valve, form ?-shaped structures that extend onto the mantle; (30) girdle view. Scanning electron microscope (SEM) internal (22) and external (23-30); (31) view of sternum valve in oblique position. Scale bars: $5 \mu \mathrm{m}$ (Fig. 22); $10 \mu \mathrm{m}$ (Figs 23,26,30,31); $2 \mu \mathrm{m}$ (Figs 24,29); $3 \mu \mathrm{m}$ (Figs 25,27,28). 

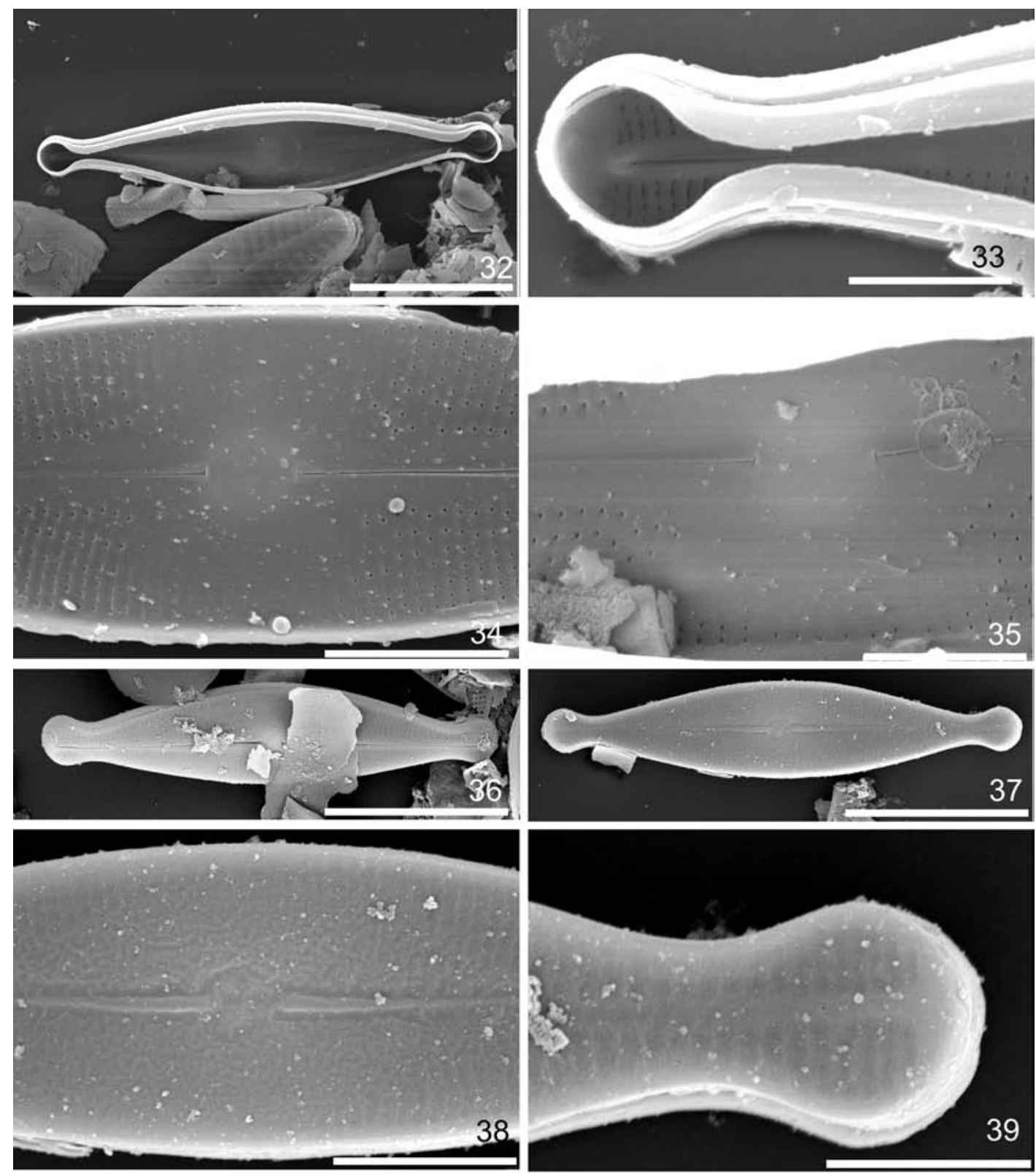

Figs 32-39 . Nupela marvanii sp. nov.: (32-35) proximal raphe fissures T-shaped. Distal raphe fissures straight, terminate in small, linear helictoglossa; (36) distal raphe fissures double-deflected extend onto the mantle; $(37,38)$ sternum valve with reinforced median costa; (39) rudimental raphe fissure. Scanning electron microscope (SEM) internal (32-35) and external (36-39) view of raphe valve (32-36) and sternum raphe (37-39). Scale bars $10 \mu \mathrm{m}$ (Figs 32,36,37); $2 \mu \mathrm{m}$ (Figs 33,35,39); 3 $\mu \mathrm{m}$ (Figs 34,38).

along pleural side of valve.

Holotypus: slide no. EU-ZTG-44 in Department of Phycology, W. Szafer Institute of Botany, Polish Academy of Sciences, Kraków, Poland, figs 11, 12.

Isotypes: Friedrich-Hustedt-Collection Alfred Wegener-Institut, Bremerhaven, Germany: ZU6/79; Academy of Natural Sciences, Philadelphia, USA, access number ANSP GC 14450; University of Szczecin, access number 14095.
Locus typicus: spring-fed pool in Polish Tatra Mts, leg. Jolanta Piątek, September 2008

Etymology: the species is dedicated to Dr. Petr Marvan, Institute of Botany, Academy of Sciences of the Czech Republic in Brno, for his great contribution to phycology and recognition of diatoms in Tatra Mts.

The most morphologically similar to Nupela marvanii is $N$. brachysiroides LANGE-BERTALOT, the species described in 1993 from Borneo 

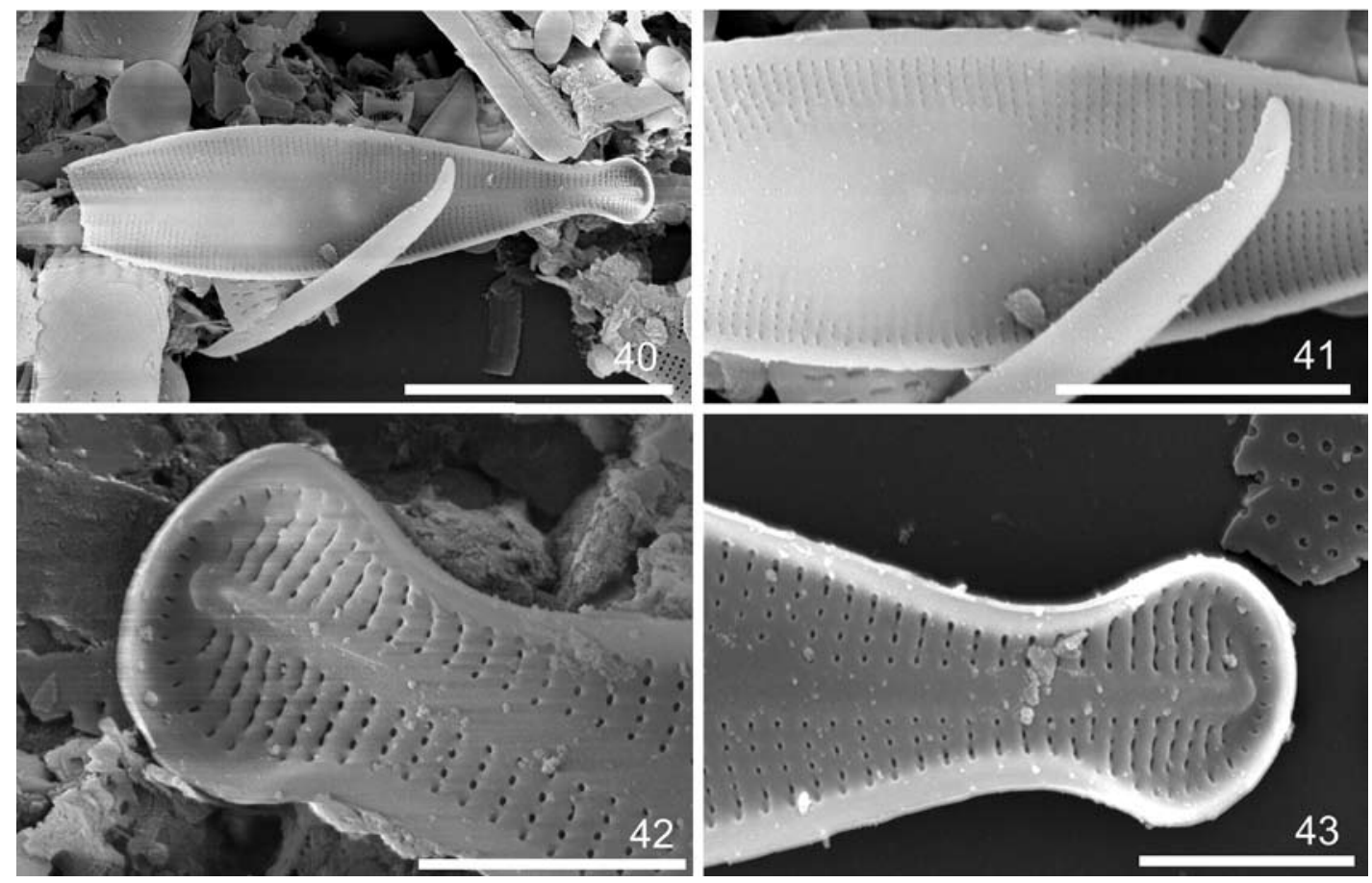

Figs 40-43. Nupela marvanii, sp. nov: $(40,41)$ linear-lanceolate axial area; $(42,43)$ rudimental raphe fissures. Scanning electron microscope (SEM) internal (40-43) view of sternum valve. Scale bars $10 \mu \mathrm{m}$ (Fig. 40); $5 \mu \mathrm{m}$ (Fig. 41); $2 \mu \mathrm{m}$ (Figs 42,43).

(Lange-Bertalot 1993; p. 154, fig 39: 1-5). $N$. marvanii is however clearly broader and more densely striated. There is no information in the Nupela brachysiroides diagnosis about its polar terminals of raphe, nor about morphology of the sternum valve.

Another similar species is Nupela impexiformis (LANGE-BerTaLOT) LANGE-BERTALOT (LANGe-Bertalot \& Krammer 1989, p. 68, figs 74: 7-9, 75: 2-4), described from an oligotrophic lake in Finland with circumneutral water of low conductivity. The species is however distinctly smaller, of more elliptical shape. Moreover, sternum valve of $N$. impexiformis possesses "fascioid" central area unilaterally expanded up to the valve margin, whereas $N$. marvanii has clearly lanceolate and only slightly asymmetric central area.

The third similar diatom is Navicula gysingensis FoGeD (1952, p.167, fig II: 7). It is also finely ornamented, "exceedingly thin", with more than 40 striae in $10 \mu \mathrm{m}$, but also clearly smaller. The whole knowledge about this diatom that might be related to the Nupela genus is limited to the original description and one drawing. It was described in presumably oligotrophic or mesotrophic running water ( $\mathrm{pH}$ more than 7 ) in
Sweden. The species described in 2004 - Adlafia multnomahii Morales et Le (Morales \& Le 2004) is also smaller and possesses quite different morphology, typical for the Adlafia genus, which is unfortunately discernible only under a scanning electron microscope.

\section{Ecology and distribution of Nupela species}

The genus Nupela which was described in 1991 (VYVERMAN \& COMPÈRE 1991) on the basis of the material collected in Papua New Guinea comprised originally two species with some suggestions that a third one might also be a member of the genus. Since that time, over 40 representatives have been recognized, including nine species described in 1927-1948, ten species described in 1973-1991 and transferred recently into Nupela genus, and over 20 species described since 1991 (Table S1; (http://fottea.czechphycology.cz). Amongst 21 species, which have been transferred so far into the Nupela genus, one belonged originally to Stauroneis [Nupela gracillima (HUSTEDT) Lange-Bertalot], eight to Achnanthes [(e.g. Nupela neogracillima (Hustedt) KULIKovskiY et Lange-Bertalot], eight to Navicula [e.g. Nupela thurstonensis (KACZMARSKA) KULIKOVSKIY, LANGEBertalot et WitKowski, three to Anomoeoneis [e.g. 
Nupela paludigena (SCHERER) LANGe-Bertalot], and one to Rhoicosphaenia [Nupela lesothensois (Schoeman) Lange-Bertalot]. Systematic position of Nupela still remains unclear (SIVER et al. 2007).

Nupela is a cosmopolitan genus, but it has the highest species richness in tropical areas (e.g. Monnier et al. 2003, Potapova et al. 2003). Its best representation in terms of species known at the moment, in Southern Hemisphere can be also related to the number of precise investigations in the area (e.g. Vyverman 1991, Lange-Bertalot \& Moser 1994, Moser 1999, Moser et al. 1998, Metzeltin \& Lange-Bertalot 1998, Rumrich et al. 2000). Recent studies revealed that Nupela might be also well represented in temperate and sub-polar zones (e.g. VAN DE VIJVER et al. 2002, Potapova et al. 2003, Siver \& Hamilton 2005, Siver et al. 2007, KulikovskiY et al. (in press)).

As with other minute taxa it is hard to assess their distribution at a species level, as they are difficult to identify under LM and several species might have been misidentified under a variety of names (Morales \& Le 2004). The literature data (Table S1; http://fottea.czechphycology.cz) correspond well with VANORMELINGEN et al (2008) opinion that diatoms distribution is influenced by general geographical factors independent of environmental conditions. Despite obvious undersampling, underreporting and poorly recognized areas and environments a present-day data suggest thet several Nupela (morpho)taxa display restricted geographical ranges and only a few of them (Nupela encyonopsis, $N$. lapidosa, $N$. vitiosa) possess a wide distribution. Autecology of several species inter allia Nupela astartiella, $N$. cymbelloidea, $N$. encyonopsis, $N$. tenuicephala, $N$. tenuistriata, $N$. vyvermanii, $N$. zizkae and several other remains almost unknown. Despite the fact that some of Nupela species can inhabit alkaline, and even organically polluted waters (POTAPOVA et al. 2003), several Nupela members inhabit oligotrophic, acidic or circumneutral waters. Oligotraphentic diatoms like Kobayasiella, Brachysira, Frustulia (e.g. Moser et al. 1998, BuczKo et al. 2009) and several Nupela taxa can be regarded as good indicators of human caused eutrophication, since their distribution is clearly restricted to natural and near-natural areas. Several species are known from springs, aerophytic habitats and/or water rich in humic matter or shaded localities which might suggest their tolerance to conditions of light limitation and might be considered as krenophilous diatoms.

\section{Acknowledgments}

I would like to express my gratitude to anonymous reviever and Prof. Dr. Aloise Poulíčková (Palacký University. Olomouc) for their valuable comments and suggestions to improve the manuscript. The author is also grateful to Dr. Jolanta Piątek and Dr. Marcin Piątek for their help during field works and Dr. Krzysztof Pawłowski (Jagiellonian University) for the diagnose translation. Author expresses gratitude to Tatra National Park staff for the permission for searching diatom flora in Tatra Mts springs. The work was partly supported by the Polish Ministry of Science and Higher Education for 2008-2011 (grant N304 092834 awarded to A.W.) and SYNTHESYS project DE-TAF-4498.

\section{References}

Antoniades, D., Hamilton, P.B., Douglas, M.S.V. \& SMOL, J.P. (2008): Diatoms of North America: the freshwater floras of Prince Patrick, Ellef Ringnes and Northern Ellesmere Islands from the Canadian Arctic Archipelago - In: LANGEBertalot, H.(ed.): Iconographia Diatomologica. Annotated Diatom Micrographs. Vol. 17. 649pp, A.R.G. Gantner Verlag K.G.

Buczko, K., Wojtal, A.Z. \& Jahn, R. (2009): Kobayasiella species of the Carpathian region: morphology, taxonomy and description of $K$. tintinnus nov. spec. - Diatom Res. 24: 1-21.

FogED, N. (1952): Diatoms in trumpet-formed catchingnets of Neureclipsis bimaculata L. in Sweden. Botaniska Notiser 2: 157-184.

Foged, N. (1981): Diatoms in Alaska. - Bibliotheca Phycol. 53: 1-317.

Hustedt, F. (1927): Bacillariales aus dem Aokikosee in Japan. - Arch. Hydrobiol. 18: 155-172.

Hustedt, F. (1937): Systematische und ökologische Untersuchungen über die Diatomeenflora von Java, Bali, und Sumatra nach dem Material der Deutschen Limnologischen Sunda-Expedition. Teil I. Systematischer Teil, Erste Fortsetzung. Arch. Hydrobiol., Suppl. 15: 187-295.

Hustedt, F. (1943): Die Diatomeenflora einiger Hochgebirgssen der Landschaft Davos in den Schweizer Alpen. Intern. - Rev. ges. Hydrobiol. 43: $124-197$.

Hustedt, F. (1962): Die Kieselalgen Deutschlands, Österreichs und der Schweiz. - In: RABENHORST, L. (ed.): Kryptogamenflora von Deutschland, Österreichs und der Schweiz, Bd 7. - pp. 161-348, Akademische Verlagsgesellschaft, Leipzig.

Index Nominum Algarum, http://ucjeps.berkeley.edu/ INA.html 
KAWECKA, B. (1970): Algae on the artificial substratum in the Wielki Staw in the Valley of the Five Polish Lakes (High Tatra Mts). - Acta Hydrobiol. 12: 423-430.

KAwECKA, B. (1971): Zonal distribution of alga communities in streams of the Polish high Tatra Mts. - Acta Hydrobiol. 13: 394-414.

KAWECKA, B. (1977): Biocenosis of a high mountain stream under the influence of tourism. 3. Attached algae communities in the stream Rybi Potok (The High Tatra Mts, Poland) polluted with domestic sewage. - Acta Hydrobiol. 19: 271-292.

KAWECKA, B.(1980): Sessile algae in European mountain streams. I. The ecological characteristics of communities. - Acta Hydrobiol. 22: 361-420.

Kawecka, B. \& Galas, J. (2003): Diversity of epilithic diatoms in high mountain lakes under the stress of acidification (Tatra Mts, Poland). - Ann. Limnol. - Int. J. Lim. 39: 239-253.

Kulikovskiy, M., Lange-Bertalot, H. \& Witkowski A. (in press): Nupela matrioschka spec. nov., Nupela thurstonensis comb. nov. and Nupela neogracillima comb et nom nov. (Bacillariophyceae); a critical analysis of their morphology. - Polish Bot. J.

LANGE-BERTALOT,H.(1993): 85 new taxa and much more than 100 taxonomic clarifications supplementary to Süßwasserflora von Mitteleuropa. 2(1-4). 27. - Bibliotheca Diatomol. 27. J. Cramer, Berlin Stuttgart.

Lange-Bertalot, H. \& Krammer, K. (1987): Bacillariaceae, Epithemiaceae, Surirellaceae. Neue und wenig bekannte Taxa, neue Kombinationen und Synonyme sowie Bemarkungen und Ergänzungen $\mathrm{zu}$ den Naviculaceae. - Bibliotheca Diatomol. 15: 1-289.

Lange-Bertalot, H. \& Krammer, K. (1989): Achnanthes, eine monographie der Gattung mit definition der Gattung Cocconeis. Bibliotheca Diatomol. 18. J. Cramer, Berlin - Stuttgart.

Lange-Bertalot, H. \& Genkal, S. (1999): Phytogeography - Diversity- Taxonomy. Diatoms from Siberia I. Islands in the Arctic Ocean (Yugorsky Shar Strait). - In: LANGeBERTALOt, H.(ed.): Iconographia Diatomologica. Annotated Diatom Micrographs. Vol. 6. - pp. 1-265, Koeltz Scientific Books, A.R.G. Gantner Verlag K.G, Vaduz.

Lange-Bertalot, H. \& Moser, G. (1994): Brachysira. Monographie der Gattung. Bibliotheca Diatomologica 29. J. Cramer, Berlin Stuttgart.

Lange-Bertalot, H. \& Metzeltin, D. (1996): Oligotrophie-Indikatoren. 800 Taxa in drei ökologisch diversen Seen-Typen. - In: LANGEBertalot, H.(ed.): Iconographia Diatomologica.
Annotated Diatom Micrographs. Vol. 2. 390pp., Koeltz Scientific Books, Koenigstein.

Lange-Bertalot, H., Kuelbs, T., Lauser, T., NörpelSchempr, M. \& Willmann M. (1996): Dokumentation und Revision der von G. Krasske beschriebenen Taxa. - In: LANGe-Bertalot H. (ed.): Iconographia Diatomologica. Annotated Diatom Micrographs Vol. 3. - 347pp., Koeltz Scientific Books, Koenigstein.

Levkov, Z., Krstic, S., Metzeltin D. \& Nakov T. (2007): Diatoms of lakes Prespa and Ochrid. About 500taxa from ancient lake system. - In: LANGEBERTALOT, H. (ed.): Iconographia Diatomologica. Annotated Diatom Micrographs. Vol. 16. Biogeography-Ecology-Taxonomy. - 417pp., A. R. G., Gantner, Ruggell, Lichtenstein.

Metzeltin, D. \& Lange-Bertalot, H. (1998): Tropische Diatomeen in Südamerika I. 700 überwiegend wenig bekannte oder neue Taxa repräsentativ als Elemente der neotropischen Flora. - In: LANGe-Bertalot, H. (ed.): Iconographia Diatomologica.Annotated Diatom Micrographs. Vol. 5. Diversity-Taxonomy-Geobotany. 695pp., Koeltz Scientific Books, Koenigstein, Germany.

Metzeltin, D. \& Lange-Bertalot, H. (2007): Tropical diatoms of South America II. Special remarks on biogeographic disjunction. - In: LANGEBertalot, H. (ed.): Iconographia Diatomologica. Annotated Diatom Micrographs. DiversityTaxonomy-Biogeography. Vol. 18. - 877pp., A. R. G. Gantner, Ruggell, Lichtenstein.

Monnier, O., Lange-Bertalot, H. \& Bertrand, J. (2003): Nupela exotica species nova: une diatomée d'un aquarium tropical d'eau douce. Avec des remarques sur la biogéographie du genre. - Diatom Res. 18: 273-291.

Morales, E.A. \& Le, M. (2004): A new species of the diatom genus Adlafia (Bacillariophyceae) from the United States. - Proceedings of the Academy of Natural Sciences of Philadelphia 154: 149-154.

Morales, E.A. \& Vis, M. (2007): Epilithic diatoms (Bacillariophyceae) from cloud forest and alpine streams in Bolivia, South America. Proceedings of the Academy of Natural Sciences of Philadelphia 126: 123-155.

Moser, G. (1999): Die Diatomeenflora von Neukaledonien. Systematic-GeobotanikÖkologie. Ein Fazit. Bibliotheca Diatomologica 43. - pp. 1-205, J. Cramer, Berlin - Stuttgart.

Moser, G., Lange-Bertalot, H. \& Metzeltin, D. (1998): Insel der Endemiten. Geobotanisches Phänomen Neukaledonien. - Bibliothieca diatomol 38. - pp. 1-464, J. Cramer, Berlin Stuttgart.

Novelo, E., Tavera, R. \& Ibarra, C. (2007): Bacillariophyceae from karstic Wetlands in 
Mexico. - Bibliothieca Diatomol 54 - pp. 1-136, J. Cramer, Berlin - Stuttgart.

Potapova, M.G., Ponader, K.C., Lowe, R. L., Clason T.A., \& BAHLS L.L., (2003): Small-celled Nupela species from North America. - Diatom Res. 18: 293-306.

ReICHARDT, E. (1988): Achnanthes praecipua n. sp., a new freshwater diatom from Mexico. In Round, F. (ed.): Proceedings of the Ninth International Diatom Symposium. - pp. 391395, Biopress Ltd., Bristol \& Koeltz Scientific Books, Koeningstein.

Rumrich, U., Lange-Bertalot, H. \& Ruppel, M. (2000): Diatoms of the Andes, from Venezuela to Patagonia/Tierra del Fuego. Iconogr. Diatomol 9. - pp. 1-649, A.R.G. Gantner Verlag K.G.

Rushforth, S.R., Kaczmarska, I. \& Johansen, J.R. (1984): The subaerial diatom flora of Thurston Lava Tube, Hawaii. - Bacillaria, 7: 135-157.

SCHERER, R.P. (1988): Freswater diatom assemblages and ecology/palaeoecology of the Okefenokee swamp/marsh complex, Southern Geaorgia, U.S.A. - Diatom Res. 3: 129-157.

SCHIMANSKI, H. (1978): Beitrag zur Diatomeenflora des Frankenwaldes. - Nova Hedwigia 30: 557633.

Siver, P.A. \& Hamilton, P.B. (2005): Observations on new and rare species of freshwater diatoms from Cape Cod, Massachusetts, USA. - Cn. J. Bot. 83: 362-378.

Siver, P.A., Hamilton, P.B. \& Morales E.A. (2007): Notes on the genus Nupela (Bacillariophyceae) including the description of anew species, Nupela scissura sp. nov. and the expanded description of Nupela paludigena. - Phycological Res. 55: 125-134.

SKALSKA, T. (1966a): The occurrence of Bacillariophyceae in a spring at Dubie. - Acta hydrobiol. 8/ Suppl. 1: 311-319.

SKALSKA, T. (1966b): Bacillariophyceae occurring in winter in a spring at Dubie near Kraków. Fragm. - Florist. geobot. 12: 233-244.

Van de Vijver, B., Frenot, Y. \& Beyens, L. (2002): Freshwater diatoms from the Ile de la Possession (Crozet Archipelago, Subantarctica). Bibliotheca Diatomol. 46: 1-412.

Vanormelingen, P., Verleyen, E. \& VyVerman, W. (2008): The diversity and distribution of diatoms: from cosmopolitanism to narrow endemism. - Biodivers. Conserv. 17: 393-405.

Vyverman, W. (1991): Diatoms from Papua New Guinea. - Bibliotheca Diatomol. 22: 1-223 + 208 pls.

VyVERMAN, W.\& COMPÈre, P. (1991): Nupela giluwensis gen. \& spec. nov. A new genus of naviculoid diatoms. - Diatom Res. 6: 175-179.

WASYLIK, K. (1971): Algal communities in the Czarny Dunajec River (Southern Poland) and some of its affluents. - Fragm. florist. geobot. 17: 257354.

Werum, M. \& Lange-Bertalot, H. (2004): Diatoms in springs from Central Europe and elsewhere under influence of hydrologeology and anthropogenic impacts. - In: LANGE-BerTALOT, H. (ed.) Iconographia Diatomologica. Annotated Diatom Micrographs. Vol. 13. - pp. 1-417, A.R.G., Gantner Verlag K. G. Ruggell.

Wydrzycka, U. \& LANGe-Bertalot, H. (2001): Las diatomeas (Bacillariophyceae) acidófilas del Río Agrio y sitios vinculados con su Cuenca, volcán Poás, Costa Rica. - Brenesia 55-56: $1-68$.

(C) Czech Phycological Society

Received April 25, 2009

Accepted June 9, 2009

Supplementary material

the following supplementary material is available for this article:

Table S1. Ecology and distribution of Nupela species.

This material is available as part of the online article (http://fottea.czechphycology.cz/contents) 


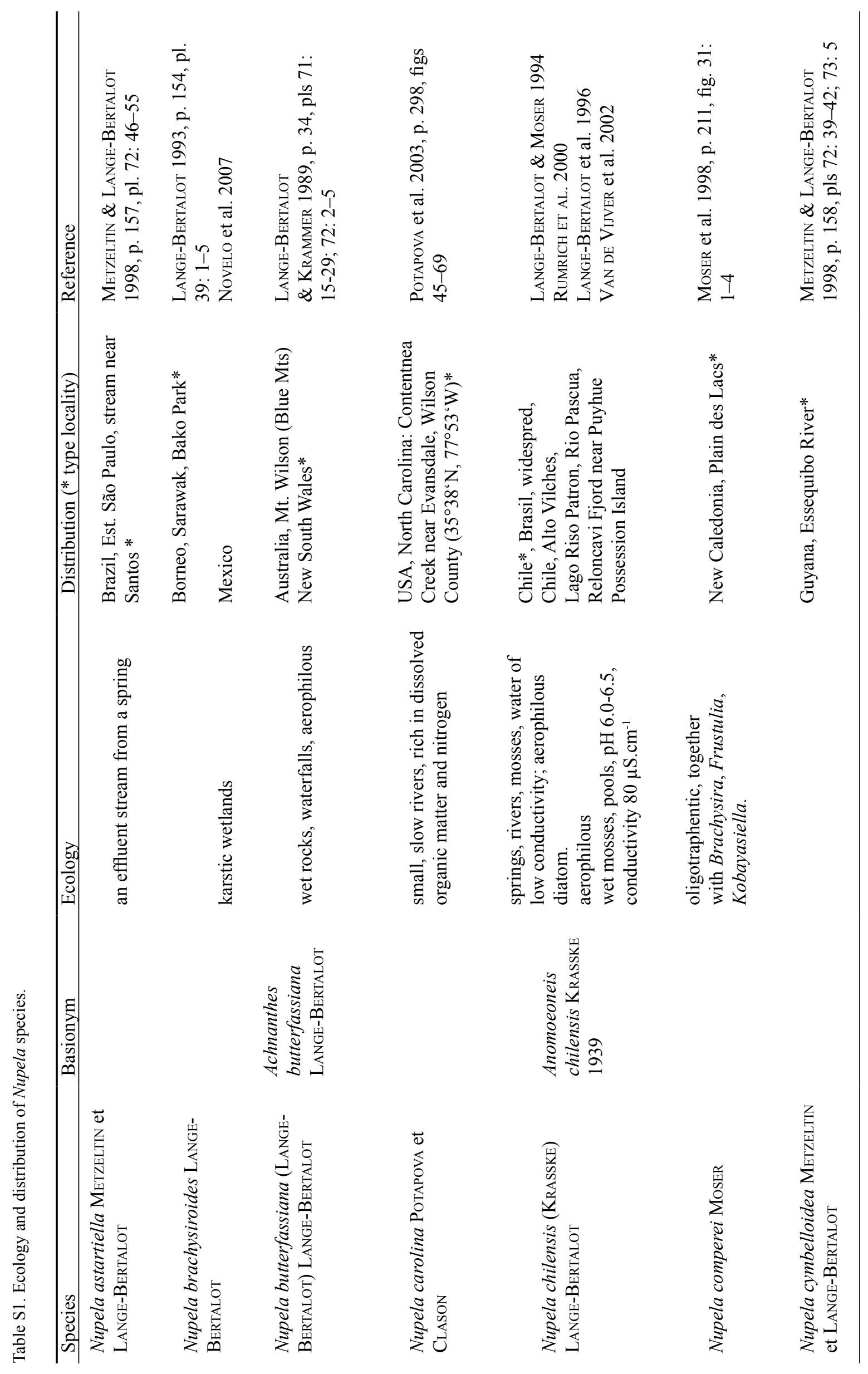




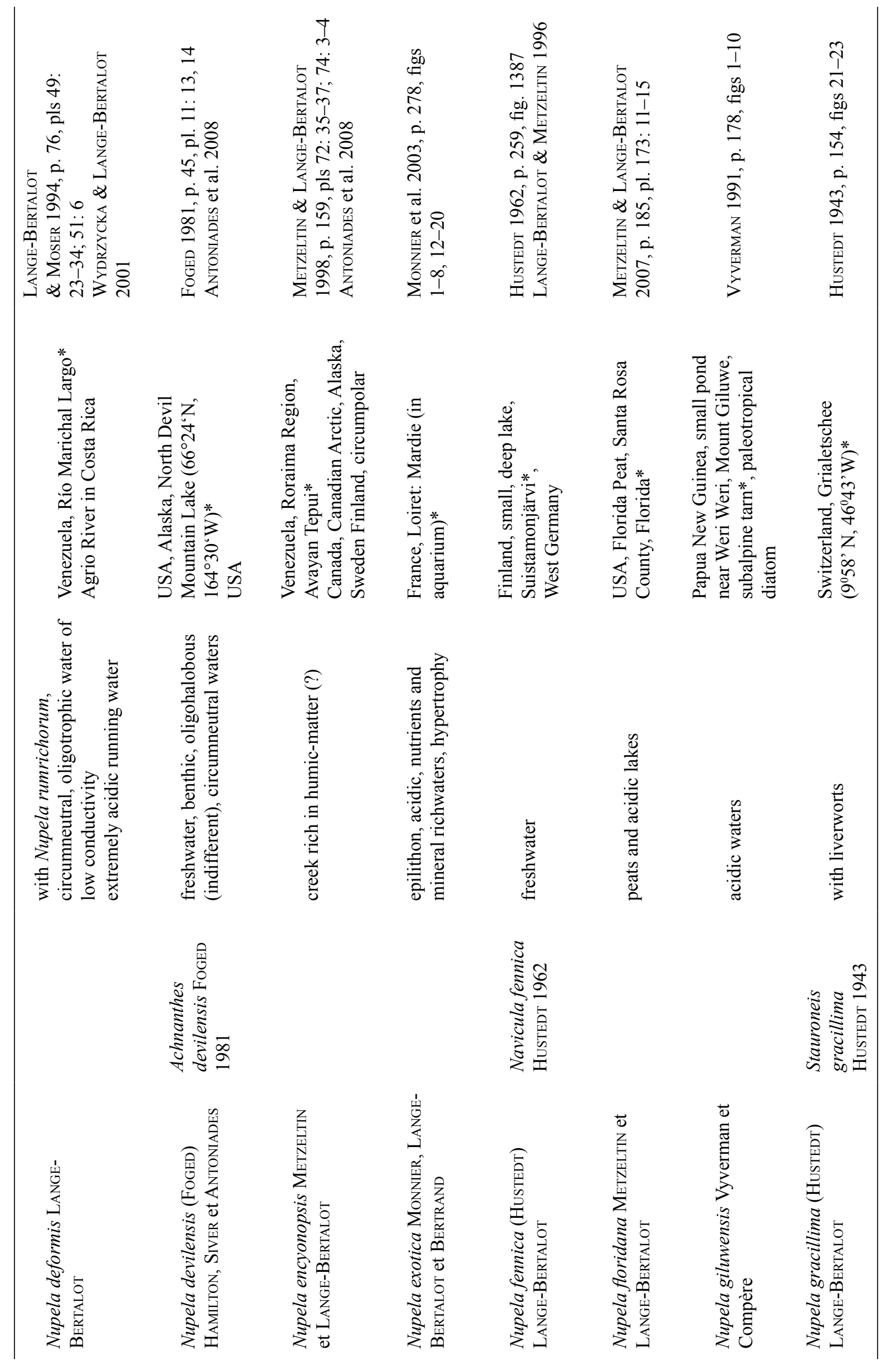




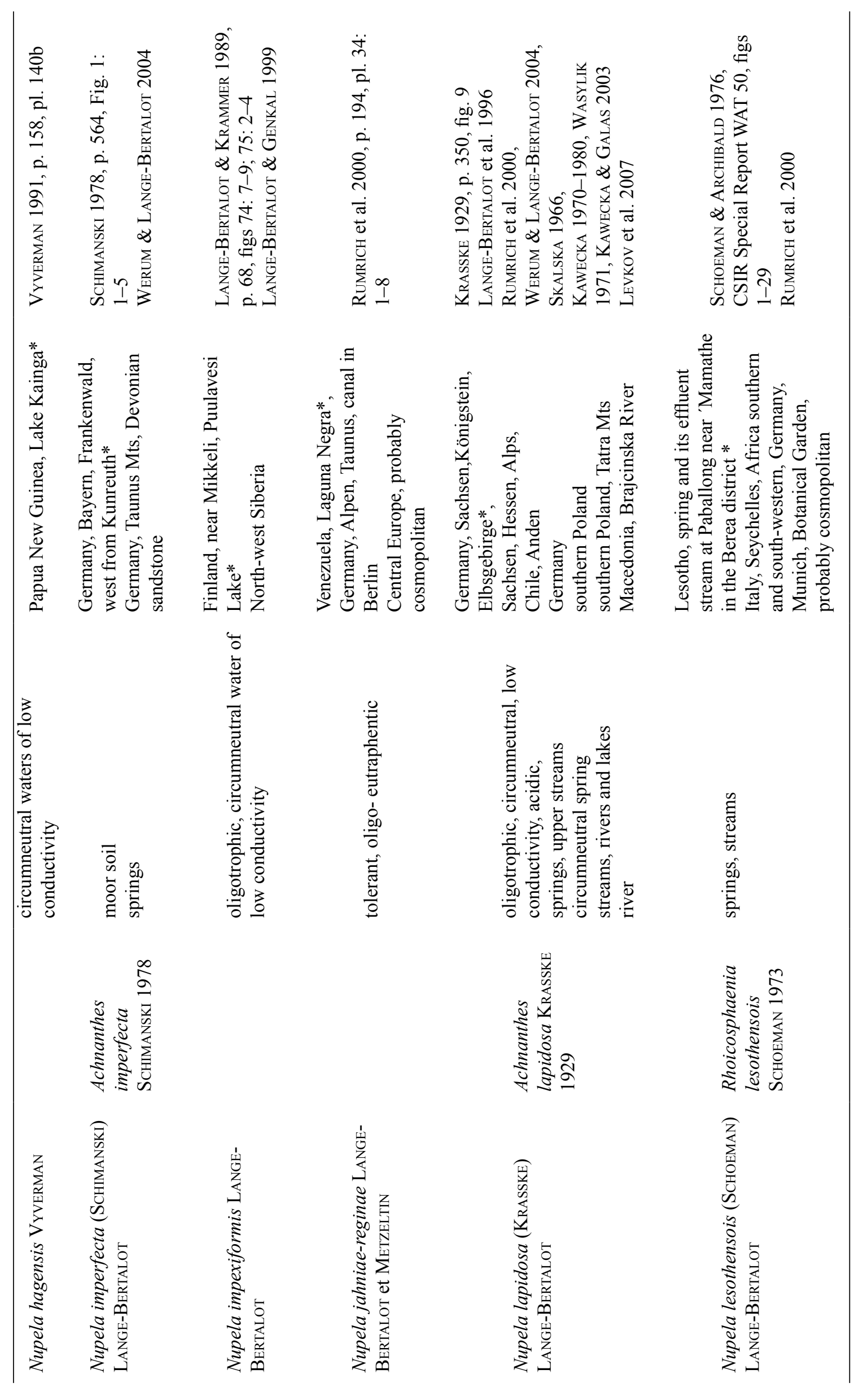




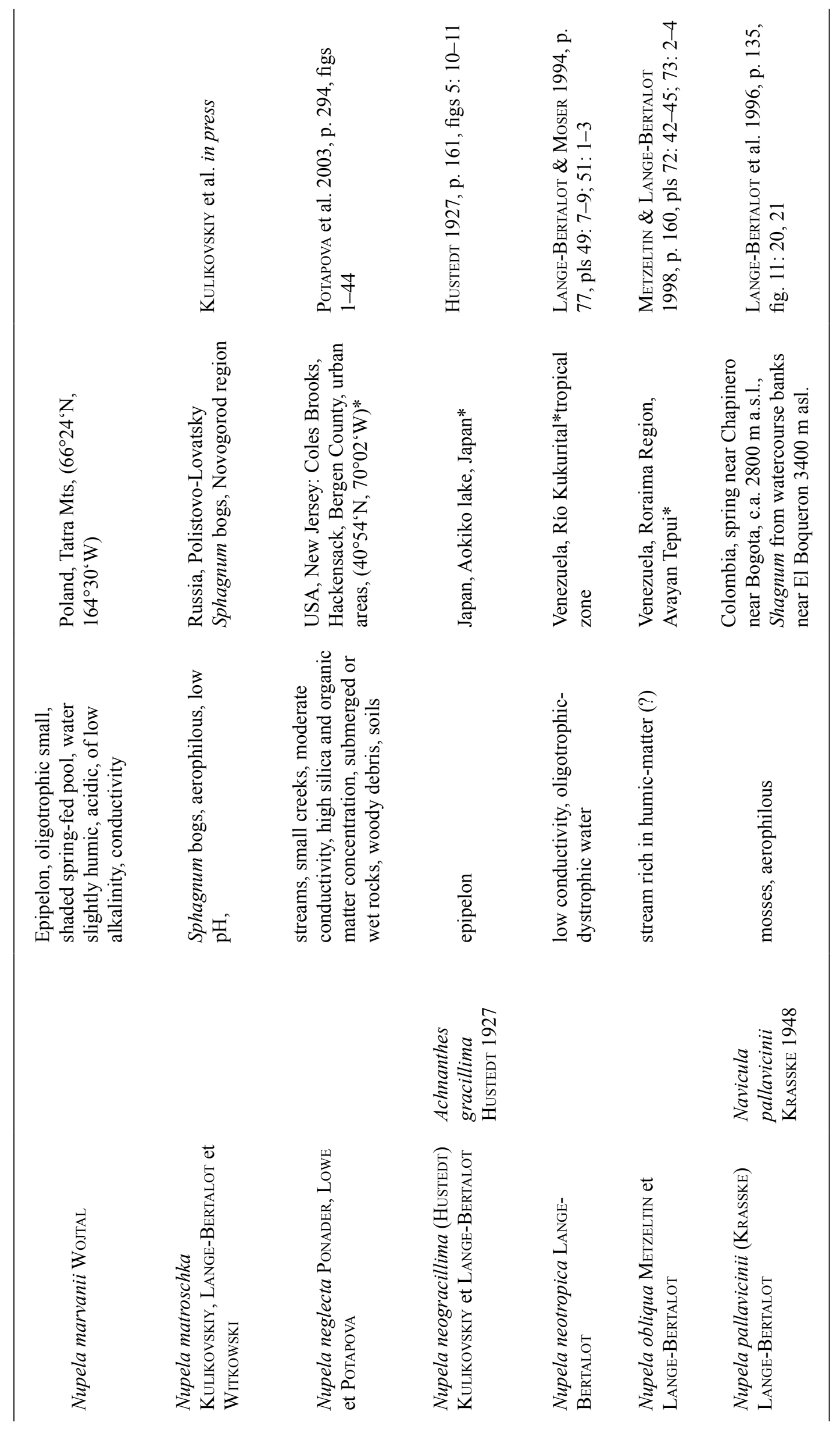




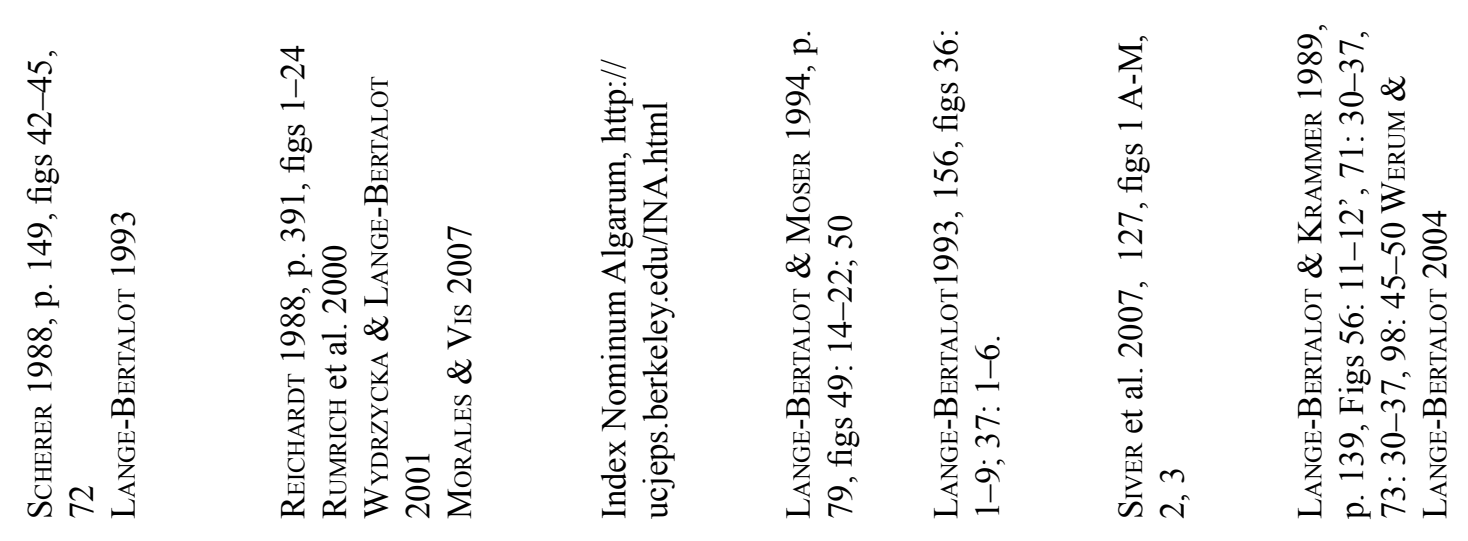

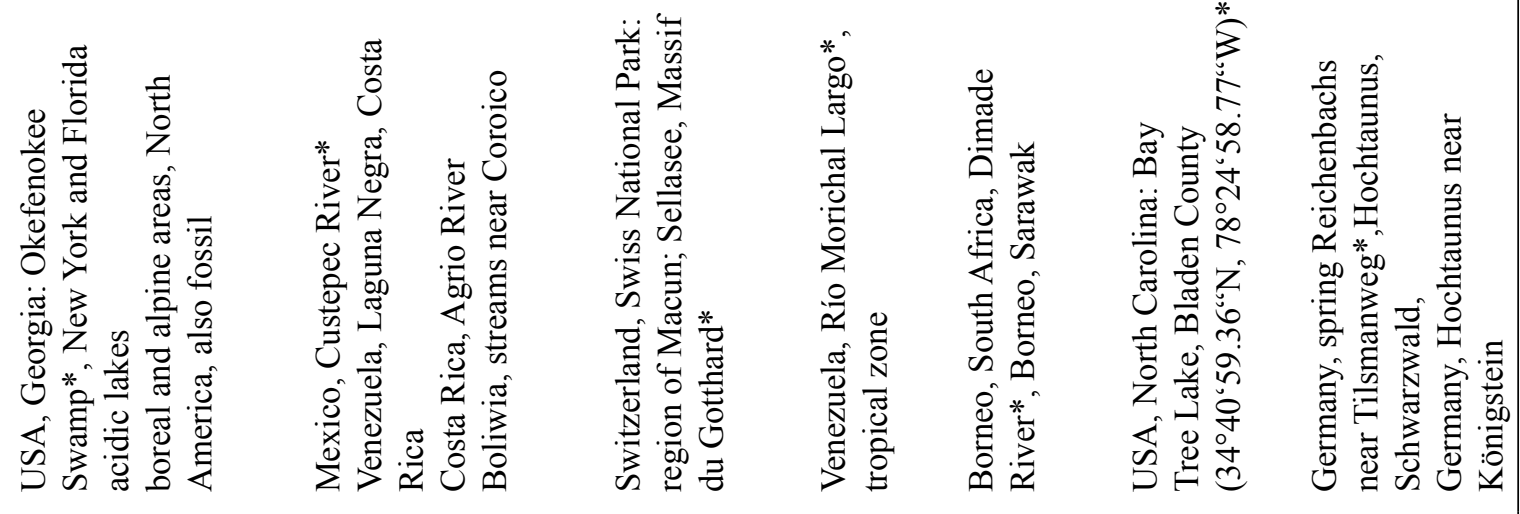
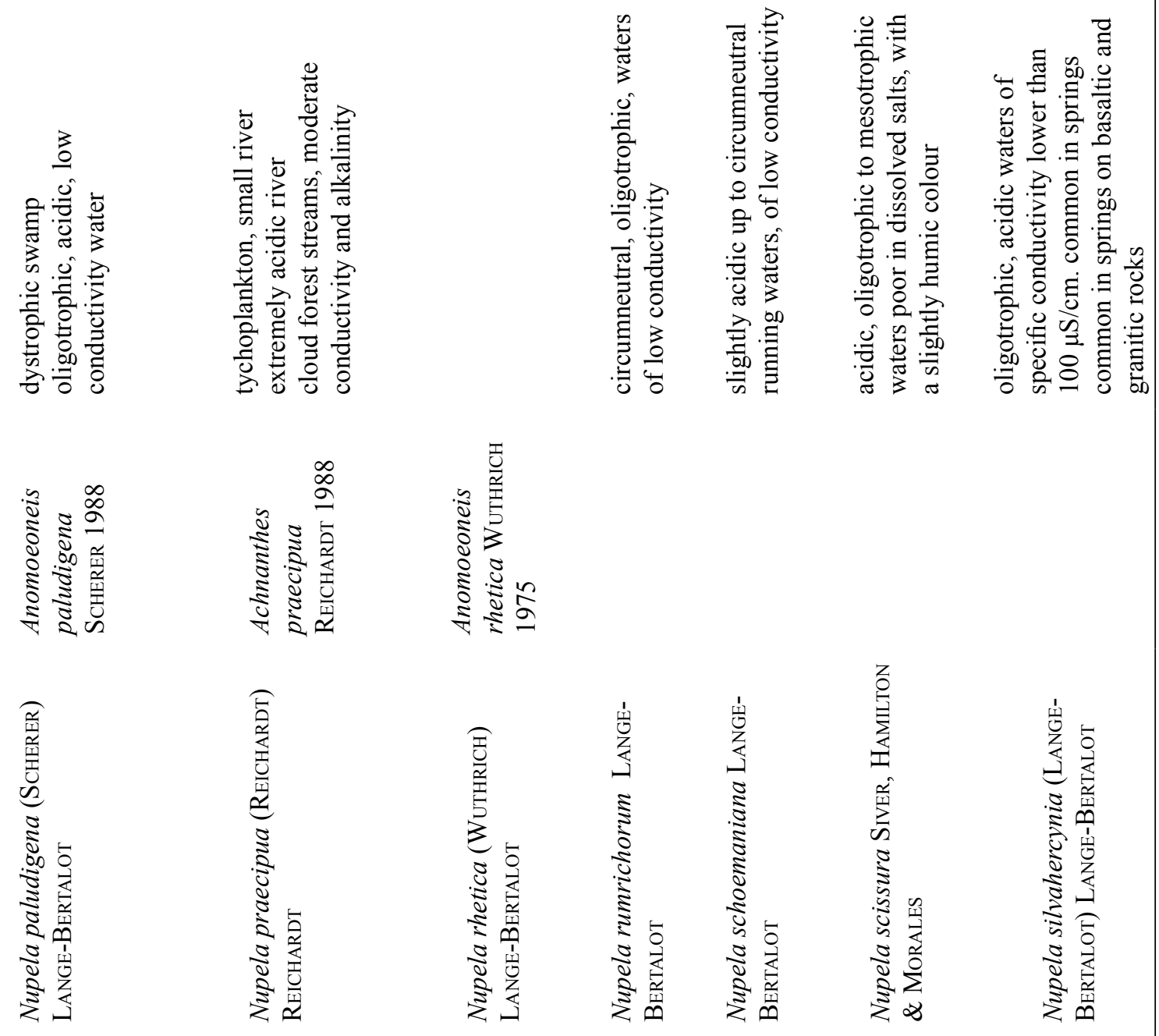


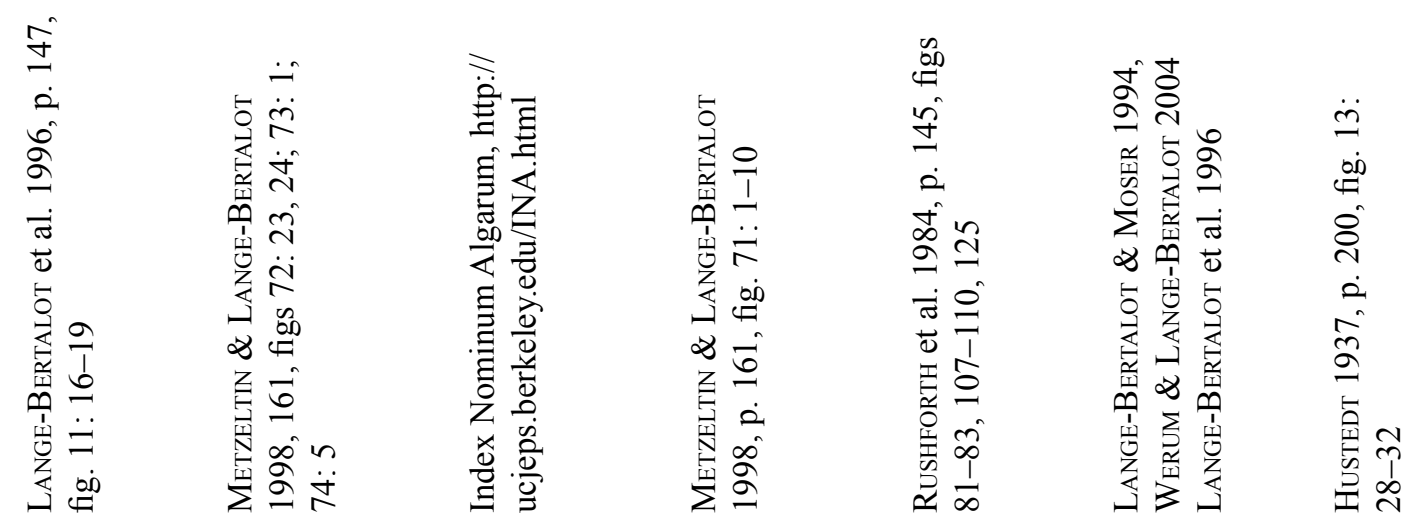

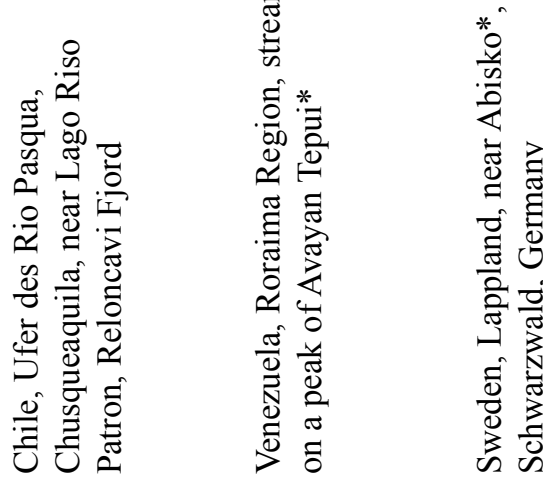
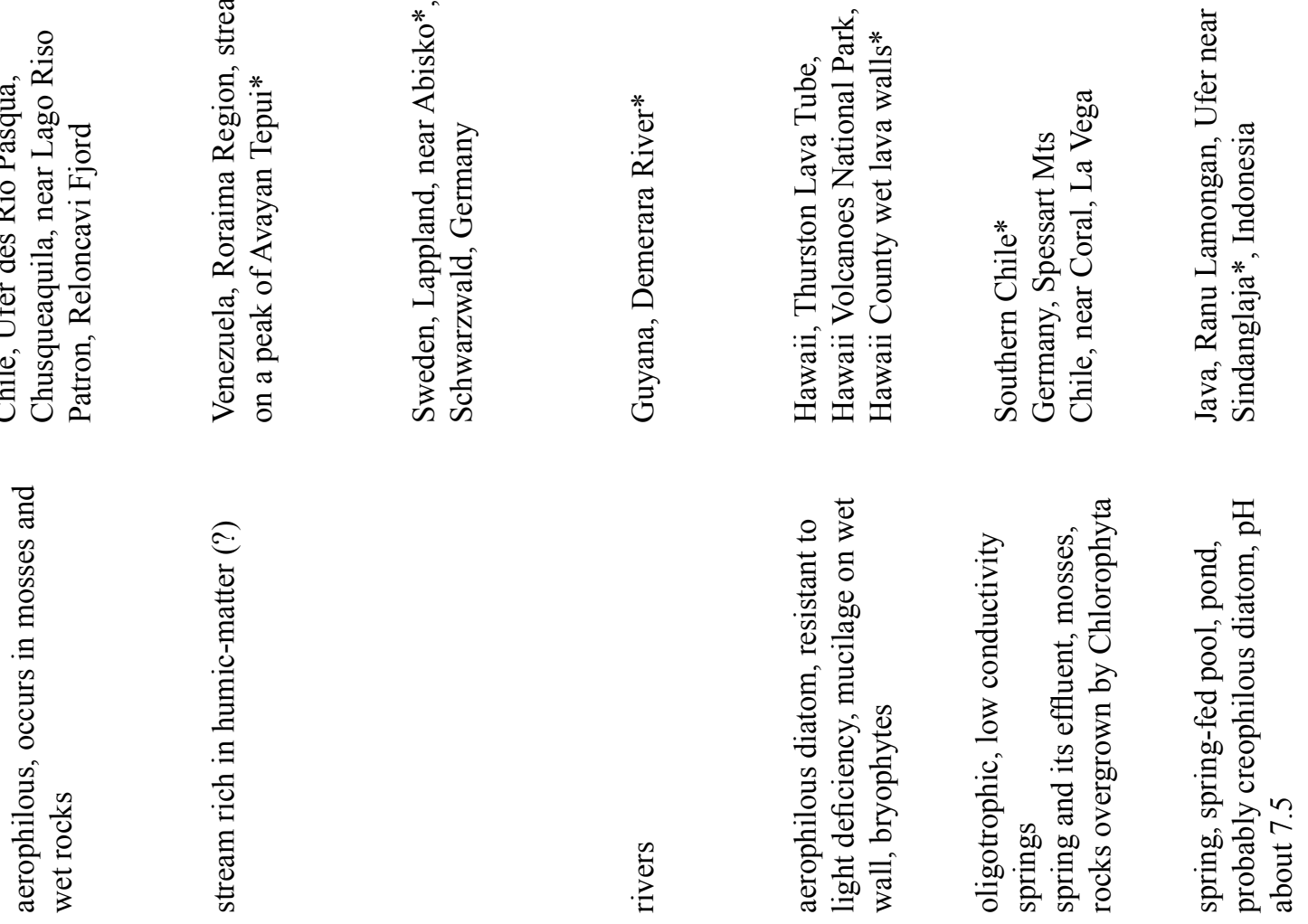

崩

$\frac{\pi}{2} \cdot \frac{2}{0}$

之. స

ชิ

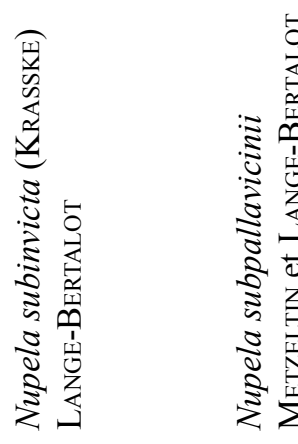

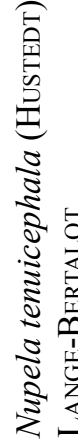

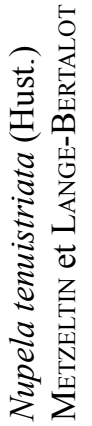

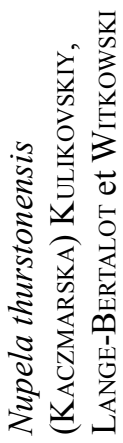

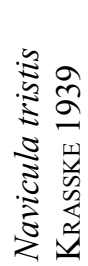

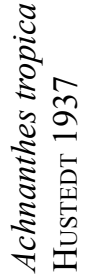

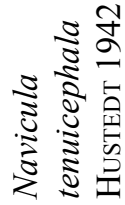
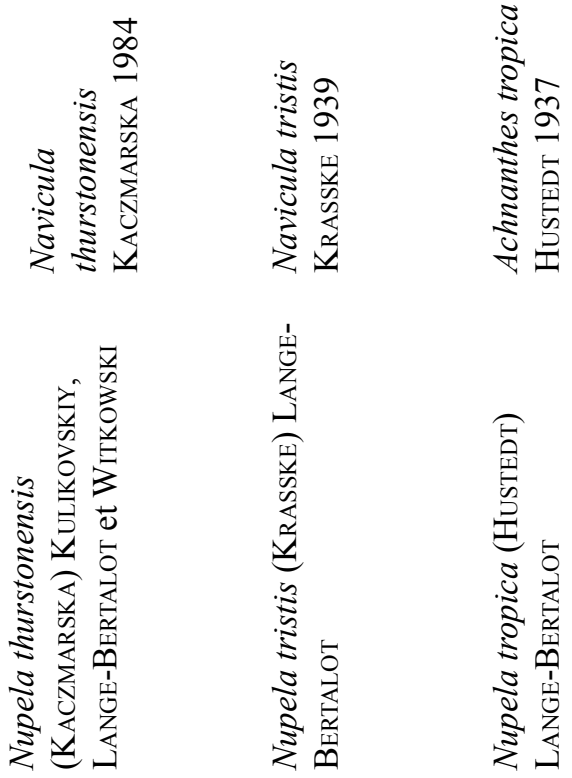


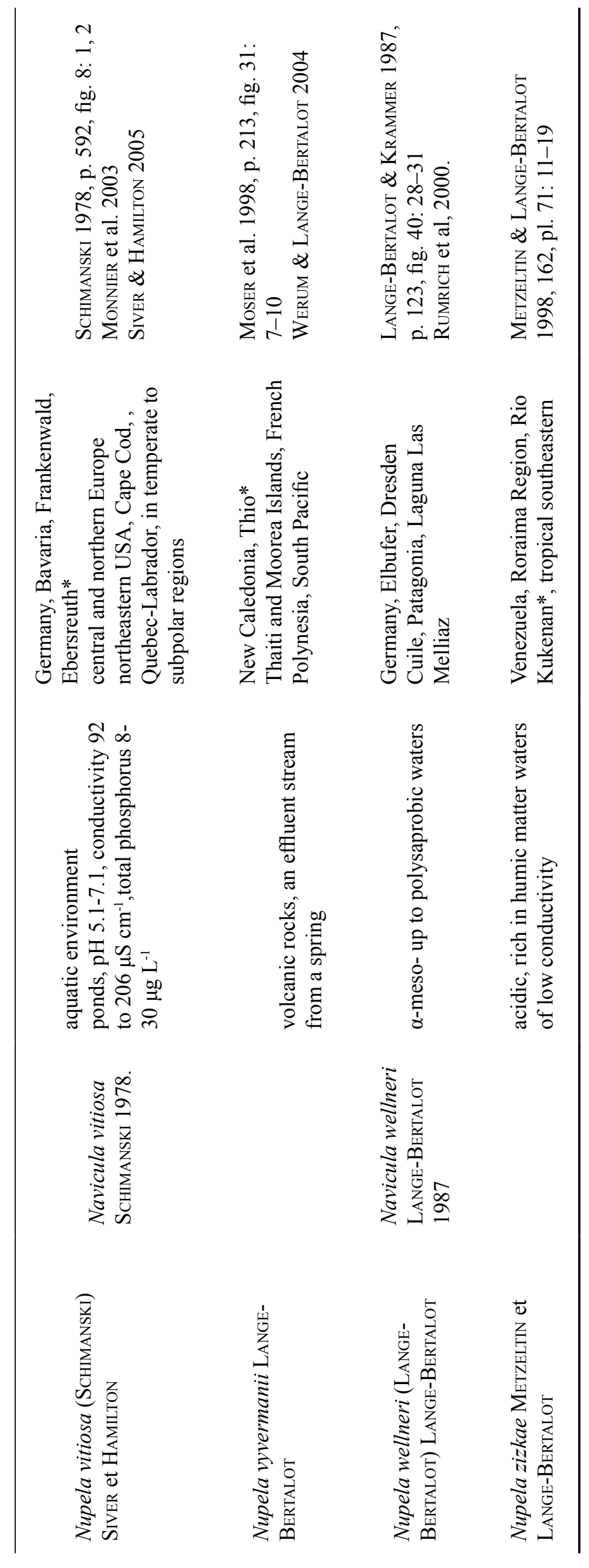

